\begin{tabular}{l}
\hline S sciendo $\frac{\text { ECONOMIC THEMES (2019) 57(3): 257-272 }}{\text { DOI 10.2478/ethemes-2019-0015 }}$ \\
\hline
\end{tabular}

\title{
MACROECONOMIC EXTERNAL (IM)BALANCES WITHIN THE EUROZONE: CORE VS PERIPHERY
}

\author{
Emilija Beker Pucar \\ University of Novi Sad, Faculty of Economics in Subotica, Republic of Serbia \\ 凶emilijabp@gmail.com;emilijab@ef.uns.ac.rs \\ Olgica Glavaški \\ University of Novi Sad, Faculty of Economics Subotica, Republic of Serbia \\ $\bowtie$ glavaski.olgica@gmail.com; olgicai@ef.uns.ac.rs
}

UDC

338.124 .4

(4-672EU)

Original scientific paper

Received:

10.10.2018

Accepted:

28.11.2019

\begin{abstract}
Since the foundation of the eurozone (EZ) until the crisis outbreak, the macroeconomic imbalances between EZ core and EZ periphery have been identified at the internal and external plan. Growing external divergence was evident in the precrisis period reflected in the chronic current account deficit of the periphery, and vice versa for the core EZ members. However, external imbalance within the EZ has been substantially narrowed in the postcrisis period. Based on the panel data framework, crucial factors of current account improvement/worsening are identified in the precrisis 1999-2007 period, as well as the postcrisis 20082017 period. Random effect model with standard errors robust to autocorrelation and heteroskedasticity is estimated, in which current account is analysed in dependence from economic growth, fiscal balance, EZ interest rate, real effective exchange rate, openness and dummy variable for the EZ core/periphery. Empirical findings for the precrisis period confirm macroeconomic overheating of the periphery as the main cause of current account worsening, while the postcrisis improvement has been achieved mainly through fiscal contraction and European Central Bank (ECB) loosened monetary stance.
\end{abstract}

Keywords: current account, eurozone, core, periphery, external adjustment, panel data models.

JEL classification: C33, F32. 


\section{Introduction}

The monetary union, as a final stage of European economic integration, was formed in 1999. The eurozone (EZ) was initially constituted from $11 \mathrm{EU}$ members $\left(12^{\text {th }}\right.$ member was Greece since 2001) which accepted the common currency and sacrificed monetary autonomy. Until now, 19 EU members accepted the euro after demanding process of a monetary convergence. Monetary union is a rigid exchange rate arrangement in which crucial sacrifice are sovereign monetary and exchange rate policy. Member countries of the EZ expect to reap higher benefits from the common currency having in mind lower exchange rate risk, lower transactional costs, less speculative attacks, and overall the ambient of macroeconomic stability. These benefits will outweigh the sacrifice if trade and financial integration are deeper between member states, if production structure is more diversified and labor/capital more mobile (Ricci, 1997; Horvath \&Komarek, 2002). If the criteria of optimum currency area (OCA) are fulfilled (Mundell, 1961) the need for a national monetary policy is reduced in order to offset idiosyncratic domestic shocks, thus making the monetary union sustainable (Rose, 2008). However, the EZ has not been created as an OCA. Vulnerability of the EZ was evident from the aspect of insufficient labour mobility since labour is largely immobile for linguistic and cultural reasons, while there is no EU budget to carry out fiscal federalism or to rescue a member state in economic difficulties (Furrutter, 2012). The problem emerging during EZ's functioning at the precrisis period was growing divergence or a dichotomy between the core and the periphery EZ members. The common currency and monetary policy cannot be successful if economies are substantially different, prone to asymmetric shocks. The global 2008 crisis revealed the vulnerability of European monetary union, culminating with the debt EZ crisis in 2010 (Baldwin \&Giavazzi, 2016).

The subject of this research is a specific aspect of EZ vulnerability, namely external position (im)balance between EZ members. In order to highlight crucial factors of current account worsening/improvement within EZ, the authors employ panel data framework in the pre-crisis 1999-2007 period and post-crisis 2008-2017 period. Since in the pre-crisis period external divergence was growing between EZ members, the question is which factors mostly initiated current account worsening in the EZ periphery. Abrupt external adjustment followed the outbreak of the global crisis, with the most burden placed on the periphery states. Key factors of external position highlighted in the model are economic growth, real effective exchange rate, fiscal balance, ECB monetary stance, openness, as well as the dummy for the core and the periphery countries. Basically, the expectation is that macroeconomic overheating of national economies, reflected in higher economic growth, real exchange rate appreciation, and worsened fiscal balance, will deteriorate external position of monetary union members. Rising openness, as a growing ratio of export in GDP, is expected to improve external position. ECB monetary contraction/loosening (rising/lowering interest rate) is expected to have 
negative/positive impact on current account balance due to higher/lower capital inflows and consequent capital account suficit/deficit necessary to cover current account deficit/suficit.

The paper is structured as follows: after introduction part, crucial internal and external imbalances within the EZ are analysed in the Section 2; methodological framework is explained in Section 3; Section 4 comprises key empirical results and their discussion; finally, concluding remarks are highlighted in Section 5.

\section{Macroeconomic internal and external imbalances in the Eurozone}

Growing literature deals with the problem of external imbalance and adjustment process, for example, Kahn and Knight (1983), Calderón et al. (1999), Chinn \& Prasad (2000), Blanchard \&Giavazzi (2002), Abiad et al. (2007), Lee et al. (2008), Decressin\&Stavrev (2009), Medina et al. (2010), Lane \&Milesi-Ferretti (2011, 2014), Chen et al. (2012), Atoyan et al. (2013), Herrmann\&Jochem (2013),Phillips et al. (2013), International Monetary Fund (2014),Cesaroni\&de Santis (2015). The motive for growing empirical interest is understandable having in mind the threat for global stability, likewise enormous economic costs related to external adjustment. Influences of the global crisis are mainly explained with macroeconomic imbalances accumulated during the period 2000-2007. The literature points that initial conditions are relevant; the countries which enter the crisis with huge internal and external imbalances recorded worse economic performances in postcrisis period (Lane \&Milesi-Ferretti, 2011; Uxó et al., 2011; Frankel\&Saravelos, 2012; Allegret\&Sallenave, 2015; Dodig\& Herr, 2015).

Current account divergence within the EZ assumes large and chronic deficit of one group of countries (Spain, Greece, Portugal, Italy and Ireland) from the one side, and suficit of another group of countries (Germany, France, Belgium, Netherlands, Finland, Austria, Luxembourg) from the other side. Monetary union based on stronger trade and financial integration, leads to lower correlation between national savings and investment. Therefore, the combination of less developed economy (periphery) with growing current account deficit is natural one. Economically weaker countries have better growth perspectives (consequently less saving) and expected higher capital returns (consequently higher investments) (Blanchard\&Giavazzi, 2002). Figure 1 (left side) shows mentioned divergence which culminated prior the crisis outbreak between the core and the periphery. Also, Figure 1 (right side) shows converging external process between the core and periphery in the post-crisis period. The contribution to the reduction in the dispersion of the current account imbalances in the EZ is coming from the reduction of the deficits while the surpluses remain at pre-crisis levels (Estrada et al., 2013). 
Figure 1. External position of EZ core and EZ periphery economies in the precrisis and postcrisis periods

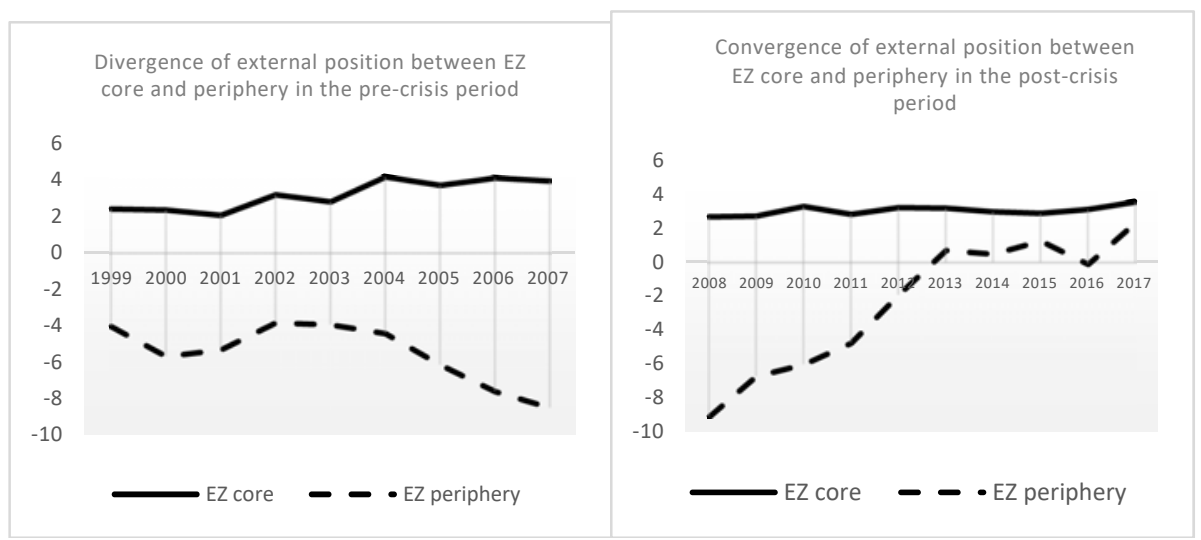

Source: Authors' review based on IMF International Finance Statistics, yearly data.

Growing divergence of external position between EZ members posed serious threats concerning following external adjustment in the absence of sovereign monetary and exchange rate policies. The question of external imbalance and adjustment is directly connected with common monetary framework since 1999 . Discipline of economic policy is of crucial importance in rigid exchange rate arrangements, such as monetary union, in order to avoid real exchange rate appreciation, competitiveness deterioration and, consequent growing and chronic current account deficit. Since the monetary policy is not under control of national economic authorities, too excessive fiscal loosening is seen as the main problem within the monetary union (Alessandrini et al., 2014; Schiliro, 2017). Figure 2 shows macroeconomic fiscal imbalance within the EZ. Fiscal position of the periphery was constantly worse, being in the deficit zone since the initiation of the EMU (Figure 2, left side). In the years following the crisis, the periphery countries went through the deeper fiscal deficit as a countercyclical reaction to the crisis. However, gradual fiscal convergence through fiscal contraction of the periphery states happened in the postcrisis period until 2018 (Figure 2, right side).

In order to maintain the competetiveness in the monetary union where developed European economies participate and share the common currency, national price levels should be under control. As Figure 2 (left side) clearly suggestes loosened fiscal stance of the periphery was apparent and, consequently, relatively higher price level could be expected. Figure 3 (left side) shows that periphery states had higher inflation in the whole precrisis period compared to the core. The inflation divergence dissappear in the postcrisis period (Figure 3, right side), as in the case of fiscal and eventually external convergence. 
Figure 2. Macroeconomic fiscal divergences in the $\mathrm{EZ}$ in the precrisis and postcrisis period

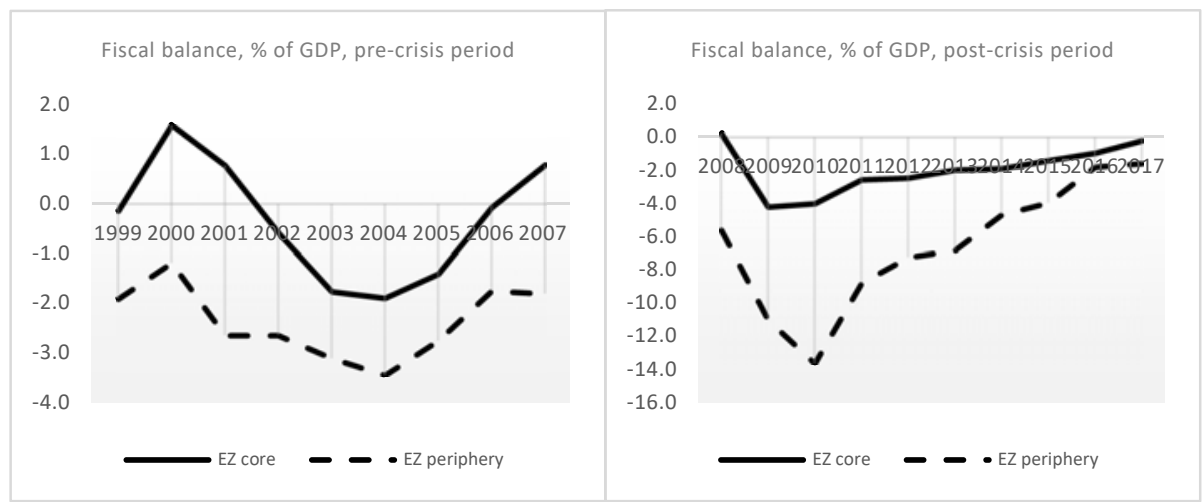

Source: Authors' review based on IMF International Finance Statistics, yearly data.

Figure 3. Inflation of the $\mathrm{EZ}$ core and $\mathrm{EZ}$ periphery in the precrisis and postcrisis period

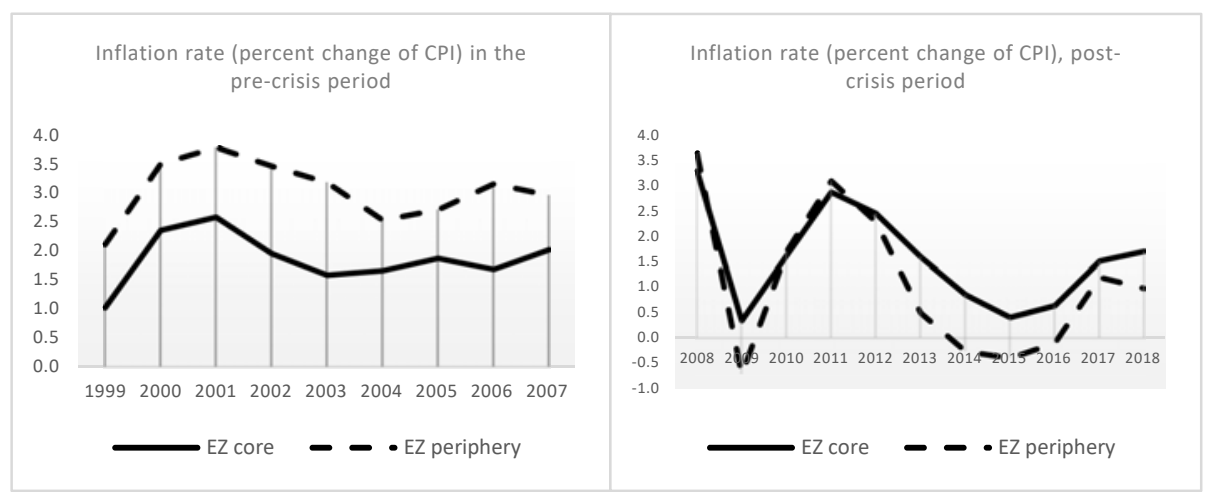

Source: Authors' review based on IMF International Finance Statistics, yearly data.

Crucial cost in monetary union's participation is lowered flexibility in adjusting the asymmetric shocks. The EZ's crisis revealed that it is not simple to achieve price adjustments without exchange rate movements, especially in low inflationary environment. Internal devaluation is costly having in mind unavoidable output loss and unemployment rise within the currency zone (Gibson et al., 2013; Wood, 2014; Beker-Pucar\&Glavaški, 2019). Since nominal exchange rate is rigidly fixed, the only way to improve competitiveness, i.e. initiate real exchange rate depreciation is via deflationary mechanism (price channel) or, the abovementioned internal devaluation or restrictive balance of payments adjustment. Figure 4 shows that competitiveness deteriorates for the periphery several years prior the crisis (left 
side). As expected and in line with previous indicators, competitiveness improvement (real exchange rate depreciation) followed the crisis because of sharp restrictive (deflationary) adjustment of the periphery (Figure 4, right side). Necessary real exchange rate depreciation in the periphery in order to retain external sustainability in the long run did not happen in the precrisis period due to capital inflows from core countries (Busch et al., 2011; Chen et al., 2012). Capital inflows, besides other factors, contributed to macroeconomic overheating of the periphery, further real appreciation with negative consequences to external position.

Figure 4. Competetiveness in the $E Z$ core and $E Z$ periphery before and after the global crisis

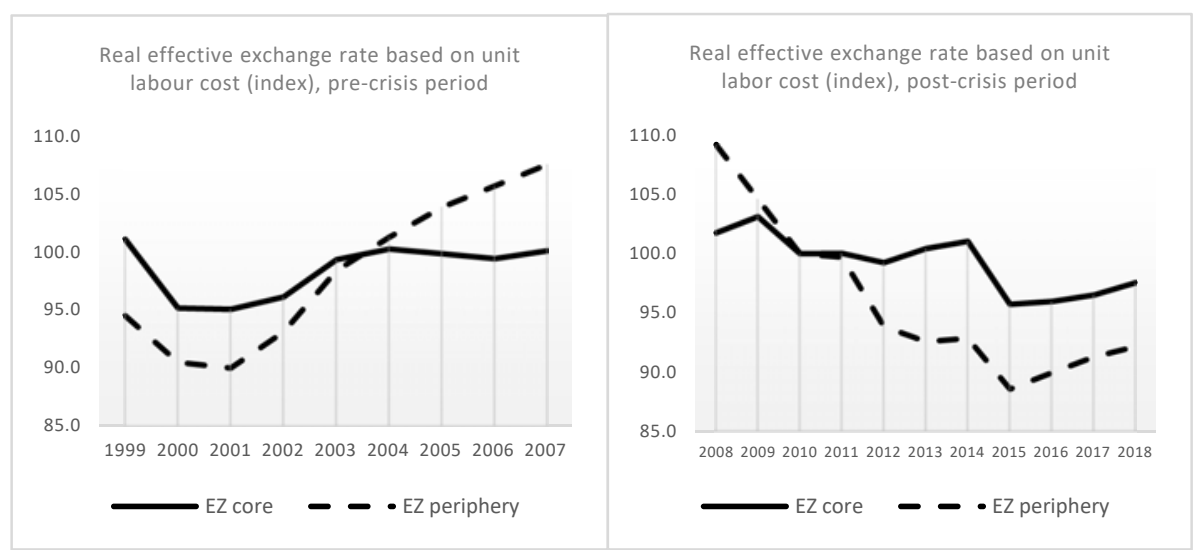

Source: Authors' review based on IMF International Finance Statistics, yearly data.

As the figures above show, the correction of flow imbalances has been impressive. Most current account deficit countries turned their deficits into balanced or surplus positions and managed to improve competitiveness. Notwithstanding the significant adjustment in flow imbalances, as Pierluigi\&Sondermann (2018) point out, several stock variables (private or public debt, net foreign assets position) remain elevated in the EZ. Therefore, despite successful convergence in the postcrisis period between the core and the periphery, EZ is still vulnerable and in need of further reforms to tackle rigidities and vulnerabilities in various parts of the economy (Dabrowski, 2015; Baldwin \&Giavazzi, 2016).

\section{Methodological framework}

Empirical analysis was conducted within panel data framework at the sample of 12 initial, developed EZ members in the precrisis 1999-2007 and the postcrisis 20082017 periods. Dependent variable, reflecting external position, is current account 
balance (cab)expressed as a percentage of GDP. Negative sign denotes deficit, while positive sign denotes current account suficit. The precrisis period 1999-2007 is the period of growing external divergence between EZ members, while the postcrisis 2008-2017 period is marked with external adjustment and crisis driven convergence between EZ members. External worsening/improvement position within $12 \mathrm{EZ}$ members in the pre- and postcrisis periods is empirically investigated considering the following empirical specification:

$$
\mathrm{cab}_{\mathrm{it}}=\alpha_{\mathrm{i}}+\sum_{\mathrm{j}} \beta_{\mathrm{j}} \mathbf{X}_{\mathbf{i t}}+\varepsilon_{\mathrm{it}},(1)
$$

where $\alpha_{i}$ are country specific (individual) effects, $\varepsilon_{\mathrm{it}}$ i.i.d error term, while explanatory variables $\mathrm{X}_{\mathrm{it}}$ consists of following regressors*:

a) Economic growth (gdpgr): rising economic growth or economic convergence of less developed European economies to the most developed is usually accompanied with current account deficit or worsening of external position. Expected sign of the estimated coefficient is negative.

b) Fiscal balance $(\mathrm{fb})$ : the hypothesis of twin deficits assumes that fiscal worsening is accompanied by external worsening (current account deficit). Fiscal expansion or deficit (fiscal worsening) is expected to be followed with current account deficit (external worsening), and vice versa. Expected sign of the estimated coefficient is positive.

c) Interest rate (ir): monetary contraction of common monetary authority (ECB) i.e. rising interest rate is usually followed by capital inflows or capital account surplus. Countries with current account deficit could finance or cover their deficit position with capital inflows (capital account suficit) due to higher ECB interest rates. The expected sign of the estimated coefficient is negative.

d) Real effective exchange rate (reer): A rise in real effective exchange rate means appreciation and worsening of competitiveness. Therefore, rise (appreciation) of a real exchange rateis accompanied with external worsening (current account deficit). Since EZ members share common currency and nominal exchange rate is fixed, real exchange rate movements are related to the domestic/foreign price changes. Macroeconomic overheating followed with higher prices inducing real exchange rate appreciation and current account deficit. And vice versa, when domestic prices fall, real exchange rate depreciated and current account improves under restrictive external adjustment process. It is well known that under rigid monetary ambient of a monetary union, monetary and fiscal loosening is unacceptable since exchange rate cannot depreciate to improve competitiveness. Undisciplined monetary and fiscal expansion is reflected in higher prices, real exchange rate appreciation and current account worsening. The expected sign of estimated coefficient is negative.

* External factors such as oil prices, economic growth of OECD members and terms of trade were initially included in the model. However, due to their statistical insignificance in both examined periods, these variables were excluded from the model. 
e) Openness (open): higher ratio of exports of goods and services in GDP is related to current account improvement, hence positive expected sign of the estimated coefficient.

f) Dummy variable (core): value 1 for Austria, Belgium, Netherland, Luxembourg, France, Germany, Finland (core EZ members) and value 0 for Ireland, Portugal, Spain, Greece, Italy (periphery EZ members). It is expected that the periphery economies record worse current account position compared to the core countries, but with narrowed difference in the postcrisis period.

Table 1 shows the details concerning dependent and explaining variables for external position model of EZ core and periphery members.

Table 1. Variable description

\begin{tabular}{|c|c|c|}
\hline Symbol & Variable description & Source \\
\hline cab & Current account balance, $\%$ of GDP & $\begin{array}{l}\text { World Bank, World } \\
\text { Development Indicators, } \\
\text { yearly data }\end{array}$ \\
\hline gdpgr & GDP growth, annual \% & $\begin{array}{l}\text { World Bank, World } \\
\text { Development Indicators, } \\
\text { yearly data }\end{array}$ \\
\hline reer & $\begin{array}{l}\text { Real effective exchange rate index } \\
(2010=100)\end{array}$ & $\begin{array}{l}\text { World Bank, World } \\
\text { Development Indicators, } \\
\text { yearly data }\end{array}$ \\
\hline fb & Government deficit/surplus, $\%$ of GDP & Eurostat, yearly data \\
\hline ir & $\begin{array}{l}\text { Money market interest rate, annual data, Euro } \\
\text { area }\end{array}$ & Eurostat, yearly data \\
\hline open & Export of goods and servies, \% of GDP & $\begin{array}{l}\text { World Bank, World } \\
\text { Development Indicators, } \\
\text { yearly data }\end{array}$ \\
\hline $\begin{array}{l}\text { The } \\
\text { dummy: } \\
\text { core }\end{array}$ & $\begin{array}{l}\text { Core EZ members (value 1): Germany, } \\
\text { France, Belgium, Luxembourg, Netherland, } \\
\text { Austria, Finland } \\
\text { Periphery EZ members (value 0): Greece, } \\
\text { Portugal, Spain, Italy, Ireland }\end{array}$ & $\begin{array}{l}\text { The dichotomy detected in } \\
\text { various papers and } \\
\text { according to authors' } \\
\text { previous descriptive } \\
\text { analysis. }\end{array}$ \\
\hline
\end{tabular}

Source: The authors.

Taking into account mentioned regressors, the model(1) becomes:

$$
\mathrm{cab}_{\mathrm{it}}=\alpha_{\mathrm{i}}+\mathrm{b}_{1} \text { gdpgr }_{\mathrm{it}}++\mathrm{b}_{2} \text { reer }_{\mathrm{it}}+\mathrm{b}_{3} \mathrm{fb}_{\mathrm{it}}+\mathrm{b}_{4} \mathrm{ir}_{\mathrm{it}}+\mathrm{b}_{5} \text { open }_{\text {it }}+\mathrm{b}_{6} \text { core }+\varepsilon_{\mathrm{it}}
$$

In order to detect the adequate panel model, various tests are performed starting with the tests of individual and time effects, Hausman specification test, 
autocorrelation and heteroskedasticity tests, as well as crosssectional dependence (CSD) tests.

The test of individual and time effects, namely F-test in fixed effect specification and Breusch-Pagan LM test in random effect specification, is based at the null hypothesis of no variation between entities against alternative hypothesis of variation between entities. If the null hypothesis is rejected, the empirical procedure continues with the autocorrelation, heteroskedasticity and CSD tests.

In order to make the choice between two key specifications, fixed or stochastic (if F test and Breusch-Pagan LM test reject null hypothesis), the Hausman test is performed. The null hypothesis of the Hausman test is that the random effects model is preferable - i.e., that the errors are not correlated with the regressors, while alternative hypothesis is that the errors are correlated with the regressors and, hence, fixed effects model should be estimated. However, when testing randomeffects (RE) model vs fixed-effects (FE) model, the traditional Hausman test cannot be used in the presence of heteroskedasticity or serial correlation. In that sense, robust Hausman test implements a (cluster)robust version of the Hausman test based on the bootstrap and does not require one of the two estimators to be fully efficient under the null hypothesis (Kaiser, 2014).

Modified Wald test and LR test are applied in FEand RE models with the null that residual variance is equal for all countries (Baum, 2001). Apart from heteroskedasticity, an autocorrelation problem with the null of no first order autocorrelation is considered with the Wooldridge test (Wooldridge, 2002; Drukker, 2003) for both specifications. Growing trade and financial integration during last decades between sample countries potentially influence stronger dependence between crosssections (EZ members). If the CSD problem is due to common factors (not included in the model as regressors, but remain within error term), while common factors are not correlated with regressors, standard FE and RE models give consistent, but inefficient estimations, while standard errors are biased (De Hoyos\&Saraffidis, 2006). Crosssectional dependence is tested with Pesaran's, Friedman's and Free's CSD tests in which the null hypothesis is the absence of CSD between countries. Depending from results of autocorrelation, heteroskedasticity and CSD tests, linear panel framework can be retained only with robust standard errors for estimated coefficients (Hoechle, 2007).

The motivation for variable selection is based on extensive literature in which current account determinants and adjustment have been explored. The pooled panel model was used in Kahn \& Knight (1983) and Estrada et al. (2013), dynamic panel model in Calderón et al. (1999) and Aristovnik (2008), classic panel framework in Chinn \& Prasad (2003) and Abiad et al. (2007), dynamic and static panel models in Cesaroni\& De Santis (2015). Relying upon macroeconomic balance approach, equilibrium current account balance was estimated with pooled and FE panel 
framework in Lee et al. (2008), Atoyan et al. (2013), Phillips et al. (2013), Medina et al. (2010), Lane \&Milesi-Ferretti $(2011,2014)$.

\section{Results and discussion}

Estimation results are based on different specification tests, as well as autocorrelation/heteroskedasticity/CSD tests (Table 2). The results of F-test for FE model and Breusch-Pagan LM test for RE model suggest the rejection of the null hypothesis or the statistical significance of individual effects. Specification choice is based on standard and robust versions of the Hausman test. Standard Hausman test indicates the acceptance of the null, hence suggests the choice of RE model. Since standard Hausman test is sensitive to heteroskedasticity and autocorrelation, before the robust Hausman test are performed different tests of heteroskedacity/autocorrelation.

Table 2. Empirical pre-estimation procedure

\begin{tabular}{|c|c|c|c|c|}
\hline \multirow[b]{2}{*}{ Test } & \multicolumn{2}{|c|}{ Pre-crisis period } & \multicolumn{2}{|c|}{ Post-crisis period } \\
\hline & FE model & RE model & FE model & RE model \\
\hline $\begin{array}{l}\text { Individual } \\
\text { effects test }\end{array}$ & $\begin{array}{l}\text { F-test: } 34.22 \\
p=0.0000\end{array}$ & $\begin{array}{l}\text { Breuch-Pagan } \\
\text { LM test: } \\
\chi^{2}=109.89 \\
p=0.0000\end{array}$ & $\begin{array}{l}\text { F-test: } 15.66 \\
p=0.0000\end{array}$ & $\begin{array}{l}\text { Breuch-Pagan } \\
\text { LM test: } \\
\chi^{2}=133.50 \\
\mathrm{p}=0.0000\end{array}$ \\
\hline $\begin{array}{l}\text { Heteroske } \\
\text { dasticity } \\
\text { test }\end{array}$ & $\begin{array}{l}\text { Wald test: } \\
\chi^{2}=338.10 \\
\mathrm{p}=0.0000\end{array}$ & $\begin{array}{l}\text { LR test: } \\
\chi^{2}=56.93 \\
p=0.0000\end{array}$ & $\begin{array}{l}\text { Wald test: } \\
\chi^{2=} 186.78 \\
p=0.0000\end{array}$ & $\begin{array}{l}\text { LR test: } \\
\chi^{2}=89.47 \\
p=0.0000\end{array}$ \\
\hline $\begin{array}{l}\text { Autocorrel } \\
\text { ation test }\end{array}$ & \multicolumn{2}{|c|}{$\begin{array}{l}\text { Wooldridge test: } \\
\mathrm{F}=11.322, \mathrm{p}=0.0063\end{array}$} & \multicolumn{2}{|c|}{$\begin{array}{l}\text { Wooldridge test: } \\
\mathrm{F}=1.551, \mathrm{p}=0.2389\end{array}$} \\
\hline CSD test & \multicolumn{2}{|c|}{$\begin{array}{l}\text { Pesaran: } 2.455, p=0.0141 \\
\text { Friedman: } 15.857, p=0.1465 \\
\text { Frees: } 0.993, p=0.5676\end{array}$} & \multicolumn{2}{|c|}{$\begin{array}{l}\text { Pesaran: } 0.247, p=0.8049 \\
\text { Friedman: } 10.164, p=0.5157 \\
\text { Frees: } 2.345, p=0.3429\end{array}$} \\
\hline $\begin{array}{l}\text { Specificati } \\
\text { on test }\end{array}$ & \multicolumn{2}{|c|}{$\begin{array}{l}\text { Hausman: } \chi^{2}=7.43, p=0.1906 \\
\text { Robust Hausman: } \chi^{2}=0.37, p=0.9960\end{array}$} & \multicolumn{2}{|c|}{$\begin{array}{l}\text { Hausman: } \chi^{2}=3.48, p=0.6257 \\
\text { Robust Hausman: } \chi^{2}=0.07 \\
p=0.9999\end{array}$} \\
\hline The model & \multicolumn{2}{|c|}{$\begin{array}{l}\text { RE model with standard errors } \\
\text { robust to autocorrelation and } \\
\text { heteroskedasticity }\end{array}$} & \multicolumn{2}{|c|}{$\begin{array}{l}\text { RE model with standard errors } \\
\text { robust to heteroskedasticity }\end{array}$} \\
\hline
\end{tabular}

Source: The authors.

Autocorrelation is statistically significant (rejection of the null) in the precrisis period and statistically insignificant (acceptance of the null) in the postcrisis period 
according to results of Wooldridge serial correlation test. At the same time, the null hypothesis of homoskedactic residuals is rejected in both periods according to modified Wald test for groupwise heteroskedacity in FE models and Likelihood ratio (LR) heteroskedacity test in RE models. Having in mind problems of autocorrelation and heteroskedacity in the precrisis period and heteroskedasticity in the post-crisis period, robust Hausman test is performed, however, with confirming results of standard Hausman test - choice of RE model. The results of Pesaran's, Friedman's and Frees's test of CSD indicate acceptance of the null hypothesis of cross-sectional independence, which is expected finding having in mind $\mathrm{T}$ and $\mathrm{N}$ dimension of this model. The absence of CSD could also point that EZ countries at the sample are heterogeneous, which is not a good sign for functioning within unique currency area.

Having in mind the above-described empirical procedure, Table 3 shows the results of REmodel of current account determinants with standard error estimates robust to disturbances that are autocorrelated and heteroskedastic in the precrisis period and autocorrelated in the postcrisis period.

Table 3. Current account determinants of all $E Z$ members in the sample, $E Z$ core and EZ periphery in pre- and post-crisis periods

\begin{tabular}{|c|c|c|c|c|c|c|}
\hline \multirow[b]{2}{*}{$\begin{array}{l}\text { Independent } \\
\text { variables }\end{array}$} & \multicolumn{3}{|c|}{ Pre-crisis period, 1999-2007 } & \multicolumn{3}{|c|}{ Post-crisis period, 2008-2017 } \\
\hline & $\begin{array}{c}\text { All EZ } \\
\text { members }\end{array}$ & Core & Periphery & $\begin{array}{c}\text { All EZ } \\
\text { members }\end{array}$ & Core & Periphery \\
\hline gdpgr & $\begin{array}{l}0.0354325 \\
(0.745)\end{array}$ & $\begin{array}{l}0.1434941^{*} \\
(0.107)\end{array}$ & $\begin{array}{l}-0.8835073^{*} \\
(0.105)\end{array}$ & $\begin{array}{l}0.0271558 \\
(0.803)\end{array}$ & $\begin{array}{l}-0.0399736 \\
(0.368)\end{array}$ & $\begin{array}{l}0.0151195 \\
(0.935)\end{array}$ \\
\hline reer & $\begin{array}{l}-0.2202967 * * \\
(0.028)\end{array}$ & $\begin{array}{l}-0.1445928 * \\
(0.110)\end{array}$ & $\begin{array}{l}-0.1872015^{*} \\
(0.078)\end{array}$ & $\begin{array}{l}-0.1531902 \\
(0.127)\end{array}$ & $\begin{array}{l}0.0060159 \\
(0.951)\end{array}$ & $\begin{array}{l}-0.078086 \\
(0.529)\end{array}$ \\
\hline fb & $\begin{array}{l}0.0223306 \\
(0.881)\end{array}$ & $\begin{array}{l}-0.0576246 \\
(0.583)\end{array}$ & $\begin{array}{l}0.473178^{*} \\
(0.096)\end{array}$ & $\begin{array}{l}0.2110073 \\
(0.140)\end{array}$ & $\begin{array}{l}0.1304076 \\
(0.299)\end{array}$ & $\begin{array}{l}0.1607483 * * \\
(0.035)\end{array}$ \\
\hline ir & $\begin{array}{l}-1.138234 * * * \\
(0.000)\end{array}$ & $\begin{array}{l}-0.8943371 * * * \\
(0.004)\end{array}$ & $\begin{array}{c}-0.7315927 \\
(0.286)\end{array}$ & $\begin{array}{c}-0.8102111^{*} \\
(0.053)\end{array}$ & $\begin{array}{c}-1.1959281 \\
(0.483)\end{array}$ & $\begin{array}{l}-1.917412 * * * \\
(0.000)\end{array}$ \\
\hline open & $\begin{array}{l}0.09124 * * * \\
(0.000)\end{array}$ & $\begin{array}{l}0.0641709 * * * \\
(0.000)\end{array}$ & $\begin{array}{l}0.0788403 * \\
(0.052)\end{array}$ & $\begin{array}{l}0.0206902 \\
(0.339)\end{array}$ & $\begin{array}{l}0.0001158 \\
(0.996)\end{array}$ & $\begin{array}{l}0.1099566 \\
(0.388)\end{array}$ \\
\hline $\begin{array}{l}\text { core } \\
\text { dummy }\end{array}$ & $\begin{array}{l}6.967165^{* * * *} \\
(0.000)\end{array}$ & & & $\begin{array}{l}4.073074 * * \\
(0.023)\end{array}$ & & \\
\hline
\end{tabular}

Note: $\mathrm{p}$-values are in parenthesis after estimated coefficient; $* * *, * *, *$ coefficient is statistically significant for $\alpha=1 \%, \alpha=5 \%, \alpha=10 \%$, respectively.

Source: The authors.

The accumulation of external deficit in the periphery EZ members and rising divergence of external position between the core and the periphery was evident in the precrisis period. According the results, statistically significant regressors for EZ members are real effective exchange rate, ECB interest rate, openness and the dummy variable core. The dummy is statistically significant pointing that the core 
countries in average have better situation concerning current account balance, around 7\% of GDP. This is confirming and expected sign of divergence between EZcore and EZ periphery in the precrisis period. For all EZ members, it could be concluded that current account worsening was initiated with real exchange rate appreciation (rise of real effective exchange rate), ECB monetary contraction (rise of ECB money market interest rate), as well as lower openness indicator (decreasing export/GDP ratio).

However, primary focus of the paper is the distinction between the core and the periphery countries. The interaction of the dummy (core) with the regressors provides the finding of main causes of current account pre-crisis deterioration for EZ periphery. It seems that current account worsening for EZ periphery during precrisis period could be attributed to macroeconomic overheating reflected in fostered economic growth, real exchange rate appreciation, worsened fiscal balance and (due to deteriorated competitiveness indicator of real exchange rate) decreased openness. Concerning the core EZ members, economic growth do not initiate worsening of the current account, while fiscal balance is not statistically significant regressor as in the case of the periphery. More favourable position of the core economies could be attributed to real exchange rate depreciation, ECB monetary contraction and rising export/GDP ratio (openness variable). The results of model estimation detect and confirm the divergence of external position between the EZ core and EZ periphery in the precrisis period.

The divergence of external position has decreased due to sharp and crisis driven external adjustment in the postcrisis period. Model estimation indicates that only ECB interest rate and the dummy core are statistically significant regressors for EZ members in the sample. ECB loosening initiates current account improvement. Fiscal balance improvement, real exchange rate depreciation and increasing openness are connected to current account improvement, but their influence is not statistically significant. Statistically significant dummy core confirms the external adjustment and decreasing divergence between the core and the periphery in the post-crisis period. It seems that the core countries in average have better external position around $4 \%$ of GDP, compared to $7 \%$ in the precrisis period. Therefore, the advantage of the core has been narrowed, but with enough space for further convergence on external plan.

By differing the core and the periphery in model estimation, the results reveal that periphery position has been improved due to positive fiscal balance as a reflection of fiscal consolidation and contraction in contrast to the pre-crisis period. Besides fiscal indicator, monetary indicator of ECB money market rate, namely its reduction in the post-crisis period, initiated current account improvement in the periphery. The statistical insignificance of economic growth, real effective exchange rate and opennesspoints to macroeconomic cooling performed mainly, as mentioned above, through fiscal consolidation and contraction. 


\section{Concluding Remarks}

The eurozone (EZ) is vulnerable if their economies diverge from external and internal equilibrium. Convergence criteria should not be regarded as a temporary adjustment with the aim of common currency acceptance. Namely, common currency and monetary union per se is endangered if convergence is not mainted in the long run. The paper identifies crucial macroeconomic imbalances between the core and the periphery of the EZ, focusing on apparent external divergence at the precrisis period. Key factors which drive external position of EZ members are economic growth, real effective exchange rate, fiscal balance, interest rate and openness. In order to distinguish the influence of the regressors to current account balance in the EZ core and the EZ periphery in the pre- and postcrisis periods, dummy variable core/periphery is introduced. Random effect models with standard errors robust to autocorrelation and/or heteroskedasticity have been estimated in order to reveal key factors of current account worsening/improvement for the sample economies. Austria, Belgium, Finland, Germany, France, Netherlands, Luxembourg are core countries, while the sample of periphery consists of Greece, Italy, Spain, Portugal and Ireland. The divergence of external position between the core and the periphery in the pre-crisis period is related to macroeconomic overheating of the periphery reflected in fostered economic growth, worsened fiscal balance, real exchange rate appreciation and openness reduction. Converging the postcrisis period was marked with sharp external adjustment under crisis impact. The empirical findings confirm reduced gap in current account position between the core and the periphery. Macroeconomic cooling of EZ periphery is visible in statistical insignificance of previous determinants and statistical significance of fiscal adjustment or contraction, contrary to the core position. Obviously, the global crisis revealed already increased macroeconomic imbalances and vulnerabilities prior to the crisis, which culminated with the EZ debt crisis. The lesson of analysed crisis episode is the need to prevent such imbalances within the $\mathrm{EZ}$, because divergence will lead up, soon or latter, to the EZ crisis under external idiosyncratic shocks. Common monetary framework cannot function properly with diverging members prone to asymmetric shocks. Our conclusions are based on statistic descriptive analysis as well as the estimations of the panel model for $12 \mathrm{EZ}$ members divided into core (7) and periphery group (5) in the precrisis (1999-2007) and postcrisis period (2007-2017). However, as the diversity is present within the EU and the EZ, it is also present within the core and within the periphery. Therefore, future research should be oriented towards the empirical investigation of specific national economies within the time series framework or within heterogeneous panel models with increased time dimension. 


\section{References}

Abiad, A.,Leigh, D. \&Mody, A.(2007).International Finance and Income Convergence: Europe Is Different(IMF Working Paper, 07/64), Washington, DC: International Monetary Fund.

Alessandrini, P., Fratianni, M., Hughes, A., \&Presbitero, F. (2014). External Imbalances and Fiscal Fragility in the Euro Area.Open Economies Review, 25 (1), 3-34.

Allegret, JP.\&Sallenave, A. (2015). Capital Flow Bonanzas and Monetary Policy in Emerging Europe: Responses to the Global Financial Crisis. Post-Communist Economies,27(4), 429447.

Aristovnik, A.(2008).Short-Term Determinants of Current Account Deficits.Eastern European Economics, 46(1), 24-42.

Atoyan, R., Manning, J. \&Rahman, J. (2013). Rebalancing: Evidence from Current Account Adjustment in Europe(IMF Working Paper, 13/74), Washington, DC: International Monetary Fund.

Baldwin, R., \&Giavazzi, F. (2016). How to Fix Europe's Monetary Union: Views of Leading Economists.London, UK: CEPR Press.

Baum, C. F. (2001). Residual Diagnostics for Cross-Section Time Series Regression Models.TheStata Journal, 1(1), 101-104.

Beker-Pucar, E. \&Glavaški, O. (2019). Monetary stages and frameworks of emerging EU members. Ekonomskihorizonti, 21(1), 29-42.

Blanchard, O. J.\&Giavazzi, F.(2002).Current Account Deficits in the Euro Area: The End of the Feldstein Horioka Puzzle?Brookings Papers on Economic Activity, 33(2), 147-210.

Busch, B., Grömling, M.\&Matthes, J. (2011). Current Account Deficits in Greece, Portugal and Spain - Origins and Consequences.Intereconomics,46(6), 354-360.

Calderón, C., Chong, A. \&Loayza, N. (1999). Determinants of Current Account Deficits in Developing Countries(Central Bank of Chile Working Paper, 51), Santiago: Central Bank of Chile.

Cesaroni, T. \&de Santis, R. (2015). Current Account 'Core-Periphery Dualism' in the EMU (LEQS Paper, 90/2015), London: The London School of Economics and Political Science.

Chinn, M. D.\&Prasad, E. (2003). Medium-Term Determinants of Current Accounts in Industrial and Developing Countries: An Empirical Exploration.Journal of International Economics, 59(1), 47-76.

Chen, R., Milesi-Ferretti,G. M.\&Tressel, T. (2012). External Imbalances in the Euro Area(IMF Working Paper, 12/236), Washington, DC: International Monetary Fund.

De Hoyos, R. E.\&Sarafidis, V.(2006).Testing for Cross-Sectional Dependence in Panel-Data Models.TheStata Journal, 6(4), 482-496.

Dabrowski, M. (2015). Monetary Union and Fiscal and Macroeconomic Governance (European Commission Discussion Paper, 13), Brussels: European Commission.

Decressin, J. \&Stavrev, E.(2009). Current Accounts in a Currency Union(IMF Working Paper, 09/127), Washington, DC: International Monetary Fund.

Dodig, N. \&Herr, H.(2015).Current Account Imbalances in the EMU: An Assessment of Official Policy Responses.Panoeconomicus, 62(2), 193-216.

Drukker, D.M. (2003). Testing for Serial Correlation in Linear Panel-Data Models.The Stata Journal, 3(2), 168-177.

Estrada, A., Gali, J.\&Lopez-Salido, D. (2013). Patterns of Convergence and Divergence in the Euro Area (Barcelona GSE Working Paper, 722), Barselona: Graduate School of Economics.

Frankel, J. A.\&Saravelos, G. (2010). Are Leading Indicators of Financial Crises Useful for Assessing Country Vulnerability? Evidence from the 2008-09 Global Crisis (NBER Working Paper, 16047), Cambridge, MA: National Bureau of Economic Research. 
Furrutter, M. (2012). The Eurozone: An Optimal Currency Area?(IFIER Papers, 02/2012), Innsbruck: IFIER.

Gibson, H. D., Palivos, T.\&Tavlas, G. T.(2013). The Crisis in the Euro Area: An Analytic Review (Special Conference Paper Bank of Greece,28), Athens: Bank of Greece.

Hoechle, D. (2007). Robust Standard Errors for Panel Regressions with Cross-Sectional Dependence.The Stata Journal, 7(3), 281-312.

Herrmann, S. \&Jochem, A. (2013). Current Account Adjustment in EU Countries: Does Euro-Area Membership Make a Difference?(Deutsche Bundesbank Discussion Paper, 49/2013), Frankfurt: Deutsche Bundesbank.

Horvath, R. \&Komarek, L. (2002). Optimum Currency Area Theory: An Approach for Thinking about Monetary Integration(The University of Warwick Working Paper, 647), Coventry: University of Warwick.

International Monetary Fund.(2014). World Economic Outlook. Washington, DC: International Monetary Fund.

Kaiser, B, (2014). RHAUSMAN: Stata module to perform a (cluster-)robust Hausman test. University of Bern.

Kahn, M. S.\&Knight, M. D. (1983). Determinants of Current Account Balances of Non-Oil Developing Countries in the 1970s: An Empirical Analysis.IMF Staff Papers,30(4), 819842.

Lane, P.R. (2010). A European Perspective on External Imbalances (SIEPS Report, 5), Stockholm: Swedish Institute for European Policy Studies.

Lane, P. R.\&Milesi-Ferretti, GM. (2012). External Adjustment and the Global Crisis.Journal of International Economics, 88(2), 252-265.

Lane, P.R.\&Milesi-Ferreti, GM.(2014).Global Imbalances and External Adjustment after the Crisis (IMF Working Paper, 14/151), Washington, DC: International Monetary Fund.

Lee, J., Milesi-Ferretti, GM., Ostry, J., Prati, A. \&Ricci, LA. (2008).Exchange Rate Assessments: CGER Methodologies(IMF Occasional Paper, 261), Washington, DC: International Monetary Fund.

Medina, L., Prat, J. \&Thomas, A.(2010). Current Account Balance Estimates for Emerging Market Economies (IMF Working Paper, 10/43), Washington, DC: International Monetary Fund.

Mundell, R. A. (1961). A Theory of Optimum Currency Areas.The American Economic Review, $51(4), 657-665$.

Pierluigi, B. \&Sondermann, D. (2018). Macroeconomic Imbalances in the Euro Area: Where Do We Stand?(ECB Occasional Paper, 211), Frankfurt: European Central Bank.

Phillips, S., Catão, L., Ricci, L., Bems, R., Das, M., Di Giovanni, J., Unsal, DF, Castillo, M., Lee, J., Rodriguez, J. \&Vargas, M. (2013). The External Balance Assessment (EBA) Methodology(IMF Working Paper, 13/27), Washington, DC: International Monetary Fund.

Ricci, L. A. (1997). A Model of An Optimum Currency Area(IMF Working Paper, 97/76), Washington, DC: International Monetary Fund.

Rose, A. K. (2008). Is EMU Becoming an Optimum Currency Area? The Evidence on Trade and Business Cycle Synchronization, Berkeley: University of California.

Schiliro, D. (2017). Imbalances and Policies in the Eurozone(MPRA Working Paper 82847), Munich: Munich Personal RePEc Archive.

Uxó, J., Paúl, J. \&Febrero, E.(2011). Current Account Imbalances in theMonetary Union and the Great Recession: Causes and Policies.Panoeconomicus,58(5), 571-592.

Wood, R. (2014). Eurozone Macroeconomic Framework: Reducing Internal and External Imbalances(MPRA Paper, 53569), Munich: Munich Personal RePEc Archive.

Wooldridge, J.M.(2002).Econometric Analysis of Cross Section and Panel Data. London: MIT Press. 


\section{MAKROEKONOMSKA EKSTERNA (NE)RAVNOTEŽA UNUTAR EVRO-ZONE: JEZGRO VS PERIFERIJA}

Rezime: Od početka funkcionisanja evro-zone (EZ) pa do izbijanja globalne krize, makroekonomske neravnoteže između zemalja jezgra i periferije EZ identifikovane su na internom, kao i na eksternom planu. Rastuća eksterna divergencija bila je evidentna u pred-kriznom periodu reflektujući hronični deficit tekućeg bilansa perifernih zemalja, i obrnuto za zemlje jezgra EZ. Međutim, eksterni disbalans unutar EZ u značajnoj meri je sužen u postkriznom periodu. $\mathrm{Na}$ bazi modela panel podataka, krucijalni faktori divergentne pozicije tekućeg bilansa su identifikovani za pred-krizni period 1999-2007, kao i post-krizni period 2008-2017. Ocenjen je model stohastičkih efekata sa standardnim greškama robusnim u odnosu na autokorelaciju i heteroskedastičnost, $\mathrm{u}$ kom je varijabla tekućeg bilansa analizirana $\mathrm{u}$ zavisnosti od regresora ekonomskog rasta, fiskalnog balansa, kamatne stope EZ, realnog efektivnog deviznog kursa, otvorenosti i veštačke varijable za jezgro/periferiju EZ. Empirijski nalazi pred-kriznog perioda ukazuju da je makroekonomsko pregrejavanje perifernih ekonomija glavni uzrok pogoršanja pozicije tekućeg bilansa, dok je post-krizno poboljšanje pozicije tekućeg bilansa uglavnom postignuto pomoću fiskalne kontrakcije i mekše monetarne pozicije Evropske centralne banke.

Ključne reči: tekući bilans, evro zona, jezgro, periferija, eksterno prilagođavanje, modeli panela.

\section{Authors' biographies}

Emilija Beker Pucar is associate professor at Faculty of Economics in Subotica, University of Novi Sad. She defended her PhD thesis at Faculty of Economics in Subotica, from the scientific field General economic theory and policy. She teaches International economics, International finance, Macrometrics and International macroeconomics at bachelor, master and doctoral academic levels. Key areas of research interest are economic policies with special focus to monetary policy and exchange rate regimes.

Olgica Glavaški is assistant profesor at Faculty of Economics in Subotica, University of Novi Sad. She defended her PhD thesis at Faculty of Economics in Belgrade from scientific field Economics. She teaches Macroeconomics of the EU, Economics of the public sector, Macrometrics, Political economy of European integration at bachelor, master and doctoral academic levels. Key areas of research interest are economic policies with special focus to fiscal policy and sustainability of public spending. 